\title{
Ethnobotanical, phytochemical and pharmacological aspects of Bengal Pogostemon (Pogostemon benghalensis)
}

\author{
Sangeeta Dahiya ${ }^{1^{*}}$, Daizy R. Batish ${ }^{1}$, Harminder Pal Singh ${ }^{2}$ \\ ${ }^{1}$ Department of Botany, Panjab University, Chandigarh 160014, India \\ ${ }^{2}$ Department of Environment Studies, Panjab University, Chandigarh 160 014, India
}

\section{A R T I C L E I N F O}

\section{Article Type:}

Review

\section{Article History:}

Received: 22 July 2019

Accepted: 29 September 2019

\section{Keywords:}

Traditional medicine

Bioactive principle

Phytochemical constituents

Pharmacological activities

Ethnobotany

\begin{abstract}
A B S T R A C T
Pogostemon benghalensis (Burm.f.) Kuntze (Lamiaceae) is an important aromatic plant. Multiple classes of phytochemicals such as flavonoids, phenols, phytosteroids, carbohydrates, fatty acids, glycosides, sterols, terpenoids, tannins, essential oil, and alkaloids have been isolated from the title species. Different plant parts have been used as traditional remedies for various ailments. The present review aims to update and coherent the fragmented information on botanical aspects, phytochemistry, traditional uses, and pharmacological activities. An extensive review of the literature was carried out by using various search engines like PubMed, Scopus, Science Direct, Google Scholar, Google, Scifinder for information. The articles were searched using the keywords "Pogostemon", "Parviflorus', "benghalensis". Chemical structures of the chemical compounds were drawn using software Chem Draw ultra 8.0. Most of the plant parts have been used for the treatment of various ailments. Phytochemistry reveals that the plant is a rich source of various biologically active compounds. Pogostemon extracts exhibited numerous pharmacological effects like anticancer, anti-inflammatory, antimicrobial and antioxidant activities. In sum, $P$. benghalensis is a promising aromatic and medicinal plant as depicted by its various traditional uses and pharmacological studies. Bioactive compounds, responsible for its various pharmacological activities at the molecular level, need further detailed investigations. Future clinical studies are also required to validate the various traditional uses of $P$. benghalensis.
\end{abstract}

Implication for health policy/practice/research/medical education:

This review represented the various useful pharmacological activities like anticancer, anti-inflammatory, antimicrobial and antioxidant activities of Pogostemon benghalensis. Further, the results of the present review revealed that essential oil and various extracts of $P$. benghalensis possess good pharmacological potential and have broad spectrum activities on various ailments such as cold, cough, pneumonia, diarrhoea, dysentery, skin diseases, and digestive problems as evident from the traditional knowledge and reported bioassays. It also provided basic information for further studies.

Please cite this paper as: Dahiya S, Batish DR, Singh HP. Ethnobotanical, phytochemical and pharmacological aspects of Bengal Pogostemon (Pogostemon benghalensis). J Herbmed Pharmacol. 2020;9(4):318-x. doi: 10.34172/jhp.2020.40.

\section{Introduction}

Plants produce a diverse assortment of secondary metabolites that do not participate directly in the growth and development of the plant (1). Due to their complex chemical structure and biosynthetic pathways, these myriad natural products have received little attention from the biological scientists. However, humans have been using the herbs and their products as medicines to cure various ailments and diseases like cough, cold, fever, digestive disorders, food poisoning, etc. since time immemorial $(2,3)$. Owing to their various traditional uses, researchers are showing more and more interest in re- evaluating and recognising various biological properties of natural plant products. Some of these natural plant products are essential oils, dyes, colouring agents, and pharmaceutical compounds. Now a day, essential oils are one of the most important secondary metabolites that are receiving considerable attention of the researchers. Because of various aromatic and therapeutic properties, these are widely used in food, flavour and fragrance, cosmetic, and other pharmaceutical industries (4).

Pogostemon benghalensis (Burm.f.) Kuntze is an aromatic undershrub that grows in open riverine forest areas of tropical climates (5) and generally found in attitudes 
between $150-1300 \mathrm{~m}$. It is native to South Asia and is widely distributed in India, Nepal, Bangladesh, Myanmar, Sri Lanka, China, Thailand, Vietnam and Bhutan $(6,7)$. The floral buds and leaves are rich in essential oil, which in turn is rich in sesquiterpenes. Various researchers have studied the chemical profile of the essential oil of $P$. benghalensis. The essential oil and the leaf extracts of $P$. benghalensis have been studied for their antioxidant (10), antibacterial (11-13), antifungal (11,13), antiviral (14), larvicidal (9) and anticancerous activities (15). Traditionally, its leaves and roots have been used to cure cold, cough, pneumonia, diarrhoea, dysentery, skin diseases, and digestive problems $(16,17)$. The present review compiles the incomplete information on the phytochemistry, traditional uses, and other pharmacological properties of $P$. benghalensis and highlights that the plants are a rich source of phytochemical worth exploiting for human benefits.

\section{Taxonomy and vernacular names}

The plant P. benghalensis (=P. fructescens J. Garham, $P$. indicus (Roth) Kuntze and P. purpuricaulis Dalzell., Origanum benghalense Burm.f., O. indicum Roth, Mentha integra Buch.-Ham. Ex Benth,) belong to Lamiaceae family of lamiales order (18). It is commonly known as Bengal Pogostemon, cockspur patchouli and has various vernacular names like Kala basing, Lujrya, raudera and Ishwar jata in Hindi, Jui-lata in Bengali, Sukloti in Assamese, Lamgi thoiding and Liriiwo in Manipuri, Pangli in Marathi, Dumobadotoko and Poksunga in Oriya, Bhoothachedayan in Malyalam, Arissikaai in Tamil, Naati pachhe thene in Kannada, Pedda tulasi, Gondripula and Kasurijang in Telugu, Niam nguang chaang in Thailand, Rudhilo and Rasangan, Basdam, Nampani (Chepang), Utajara (Danuwar), Rutili (Tamang), Kali-bant (Tharu) in Nepalese, and Kali suhali in Pakistan.

\section{Botanical description}

Pogostemon benghalensis is an undershrub to shrub with a strong, solid, angular and tomentose stem. The leaves are ovate with double dentate margin and acuminate apex, pubescent and bear epidermal hairs and secretary structures, arranged in opposite phyllotaxy (19). It bears purple or pinkish-white bilipped flowers with strong aroma in verticillaster inflorescence; stamens are exerted with long violet purple hairs on filaments; the ovary is glabrous with slenderical style and bilobed stigma (20, $21)$. Fruits are trigonous, reddish brown and composed of four nutlets.

\section{Phytochemistry}

A little work has been done on the photochemistry of P. benghalensis. As per studies done using GC-MS (gas chromatography- mass spectrometer), the plant has a rich profile of phytochemicals like phenolics, steroids, tannins, flavonoids, terpenoids, and essential oils. The crude extracts and essential oils are mainly composed of sesquiterpenes, but also have terpene derivatives, aromatic alcohols and other organic compounds $(5,6,8,9)$.

In a study performed by Chanotiya et al, Elemol (11.6$20.5 \%), \quad \beta$-caryophyllene $\quad(8.1-12.5 \%), \quad \beta$-bisabolene (3.6\%-18\%), $\alpha$-humulene (4.0-8.7\%), $\beta$-ocimene (3.6$3.7 \%)$, germacrene B $(2.5-4.8 \%)$, were reported as the major components in Pogostemon oil extracted from leaves and inflorescence of the plant (8). Moreover, the presence of these components was also confirmed by Bhuiyan et al (6). In a similar study of the phytochemistry of Pogostemon, Anjana and Thoppil (9) reported dehydranone $(26.66 \%)$ as major component followed by $\delta$-cadinol (23.06\%) whereas, in contrast, Dhakal et al (5) reported 7-Isopropyl-1,4-dimethyl-azulen-2-ol (41.72\%) as the major component followed by a-gurjunene isomer (9.23\%). The variations observed in the chemical profile of $P$. benghalensis could have been possibly due to differences in geographical location, climatic conditions, harvesting methods, the growth stage of the target plant at the time of harvesting, plant parts used for oil extraction, soil profile etc. Some of the important components detected in the essential oil of $P$. benghalensis, along with their known pharmacological properties are given in Table 1 (22-63).

\section{Nutritive value}

Nutrient analysis of the leaves of $P$. benghalensis by Unni et al revealed the presence of approximately $0.25 \pm 0.1 \%$ carbohydrates, $6.175 \pm 0.2 \%$ fatty acids, $4.59 \pm 0.1 \%$ proteins, $7.10 \pm 0.1 \%$ fibre, $1.6 \pm 0.2 \%$ tannin, $84.77 \pm 2.4 \%$ moisture, and $75.01 \pm 1.6 \%$ nutritive value. The investigators also determined the fatty acid composition through GC analysis after converting lipids into methyl esters which ensured the presence of methyl ester of palmitic acid $(0.75 \%)$ and a mixture of oleic, linoleic and linolenic acids (3.75\%), of which linoleic and linolenic are the essential fatty acids for human beings (64).

\section{Ethnobotanical uses}

Different parts of $P$. benghalensis have been traditionally used by different ethnic groups in India and other countries for domestic and therapeutic purposes. Generally, genus Pogostemon was used by tribal people for its roots and leaves (65). Different plant parts were used in formulations like decoction, fresh extract, poultice, and infusion etc. to get rid of health ailments. The plant is used as an antidepressant, antiseptic, aphrodisiac and to cure skin problems in aromatherapy (64). It has been widely used in folk medicine for the treatment of intestinal disorder and intermittent fever (66). Tribal people also used the plant as an antidote to snakebite. The paste of soft leaves and fresh roots was applied to the snake bites. Boiled root extract was orally given to the patient (67). Traditionally, leaf and root juice have been given to cure cough and cold $(11,68)$, haemorrhage $(69)$, malaria, 
Table 1. List of chemical components of essential oil of Pogostemon benghalensis with their known pharmacological activities

\begin{tabular}{|c|c|c|c|}
\hline $\begin{array}{l}\text { Compound, Molecular formula, } \\
\text { M. weight, nature }\end{array}$ & Chemical structure & Structure ID & Pharmacological properties \\
\hline $\begin{array}{l}\text { Benzaldehyde } \\
\mathrm{C}_{7} \mathrm{H}_{6} \mathrm{O} \\
106.124 \mathrm{~g} / \mathrm{mol} \\
\text { Aromatic aldehyde }\end{array}$ & & $\begin{array}{l}\text { PubChem CID } \\
240\end{array}$ & Larvicidal (22) \\
\hline $\begin{array}{l}\alpha \text {-Pinene } \\
\mathrm{C}_{10} \mathrm{H}_{16} \\
136.238 \mathrm{~g} / \mathrm{mol} \\
\text { Monoterpene }\end{array}$ & & $\begin{array}{l}\text { PubChem CID } \\
6654\end{array}$ & $\begin{array}{l}\text { Anti-inflammatory (23), antibacterial, } \\
\text { antitumor (24), antioxidant (25), fumigant } \\
\text { (26), analgesic (27) }\end{array}$ \\
\hline $\begin{array}{l}p \text {-Cymene } \\
\mathrm{C}_{10} \mathrm{H}_{14} \\
134.222 \mathrm{~g} / \mathrm{mol} \\
\text { Monoterpene }\end{array}$ & & $\begin{array}{l}\text { PubChem CID } \\
7463\end{array}$ & $\begin{array}{l}\text { Anti-inflammatory (28), antioxidant (25), } \\
\text { antitumor (28), analgesic (29) }\end{array}$ \\
\hline $\begin{array}{l}\beta \text {-Ocimene } \\
\mathrm{C}_{10} \mathrm{H}_{16} \\
136.238 \mathrm{~g} / \mathrm{mol} \\
\text { Monoterpene }\end{array}$ & & $\begin{array}{l}\text { PubChem CID } \\
5281553\end{array}$ & Antioxidant (25), nematicidal (30) \\
\hline $\begin{array}{l}\gamma \text {-Terpinene } \\
\mathrm{C}_{10} \mathrm{H}_{16} \\
136.238 \mathrm{~g} / \mathrm{mol} \\
\text { Monoterpene }\end{array}$ & & $\begin{array}{l}\text { PubChem CID } \\
7461\end{array}$ & $\begin{array}{l}\text { Anti-inflammatory (28), antioxidant (25), } \\
\text { insecticidal (31) }\end{array}$ \\
\hline $\begin{array}{l}\text { Linalool } \\
\mathrm{C}_{10} \mathrm{H}_{18} \mathrm{O} \\
154.253 \mathrm{~g} / \mathrm{mol} \\
\text { Monoterpene alcohol }\end{array}$ & & $\begin{array}{l}\text { PubChem CID } \\
6549\end{array}$ & $\begin{array}{l}\text { Antitumor (32), anti-inflammatory (33), } \\
\text { fumigant (34), anesthetic and sedative } \\
\text { agents (35), analgesic (36) }\end{array}$ \\
\hline $\begin{array}{l}\text { Borneol } \\
\mathrm{C}_{10} \mathrm{H}_{18} \mathrm{O} \\
154.253 \mathrm{~g} / \mathrm{mol} \\
\text { Monoterpene alcohol }\end{array}$ & & $\begin{array}{l}\text { PubChem CID } \\
439569\end{array}$ & $\begin{array}{l}\text { Antitumor (37, 38), analgesic (39), } \\
\text { antioxidant ( } 25) \text {, fumigant ( } 40), \\
\text { trypanocidal (41) }\end{array}$ \\
\hline $\begin{array}{l}\beta \text {-Elemene } \\
\mathrm{C}_{15} \mathrm{H}_{24} \\
204.357 \\
\text { Sesquiterpene }\end{array}$ & & $\begin{array}{l}\text { PubChem CID } \\
6918391\end{array}$ & Anti-inflammatory (42), apoptotic (43) \\
\hline $\begin{array}{l}\text { Cyclosativene } \\
\mathrm{C}_{15} \mathrm{H}_{24} \\
204.357 \\
\text { Sesquiterpene }\end{array}$ & & $\begin{array}{l}\text { PubChem CID } \\
519960\end{array}$ & Antioxidant (44) \\
\hline $\begin{array}{l}\alpha \text {-Copaene } \\
\mathrm{C}_{15} \mathrm{H}_{24} \\
204.357 \\
\text { Sesquiterpene }\end{array}$ & & $\begin{array}{l}\text { PubChem CID } \\
25245021\end{array}$ & $\begin{array}{l}\text { Analgesic and anti-inflammatory (45), } \\
\text { antigenotoxic (46) }\end{array}$ \\
\hline $\begin{array}{l}\beta \text {-Caryophyllene } \\
\mathrm{C}_{15} \mathrm{H}_{24} \\
204.357 \\
\text { Sesquiterpene }\end{array}$ & & $\begin{array}{l}\text { PubChem CID } \\
5281515\end{array}$ & $\begin{array}{l}\text { Leishmanicidal (47), Anti-endemic, Anti- } \\
\text { tumor, Anti-oxidant, Anti-microbial and } \\
\text { Anti-inflammatory (48), Antioxidant46 }\end{array}$ \\
\hline $\begin{array}{l}\alpha \text {-Humulene } \\
\mathrm{C}_{15} \mathrm{H}_{24} \\
204.357 \\
\text { Sesquiterpene }\end{array}$ & & $\begin{array}{l}\text { PubChem CID } \\
23204\end{array}$ & Anti-inflammatory (49), Antioxidant (25) \\
\hline
\end{tabular}


Table 1. Continued

\begin{tabular}{|c|c|c|c|}
\hline $\begin{array}{l}\text { Compound, Molecular formula, } \\
\text { M. weight, nature }\end{array}$ & Chemical structure & Structure ID & Pharmacological properties \\
\hline $\begin{array}{l}\text { Alloaromadendrene } \\
\mathrm{C}_{15} \mathrm{H}_{24} \\
204.357 \\
\text { Sesquiterpene }\end{array}$ & & $\begin{array}{c}\text { PubChem CID } \\
91746537\end{array}$ & Antiproliferative (50) \\
\hline $\begin{array}{l}\text { Germacrene D } \\
\mathrm{C}_{15} \mathrm{H}_{24} \\
204.357 \\
\text { Sesquiterpene }\end{array}$ & & $\begin{array}{l}\text { PubChem CID } \\
5373727\end{array}$ & Aphid repellent (51), Mosquitocidal (52) \\
\hline $\begin{array}{l}\text { Valencene } \\
\mathrm{C}_{15} \mathrm{H}_{24} \\
204.357 \\
\text { Sesquiterpene }\end{array}$ & & $\begin{array}{l}\text { PubChem CID } \\
9855795\end{array}$ & Antioxidant (25) \\
\hline $\begin{array}{l}\alpha \text {-Bulnesene } \\
\mathrm{C}_{15} \mathrm{H}_{24} \\
204.357 \\
\text { Sesquiterpene }\end{array}$ & & $\begin{array}{l}\text { PubChem CID } \\
\quad 94275\end{array}$ & Antiplatelet aggregation agent (53) \\
\hline $\begin{array}{l}\delta \text {-Cadinene } \\
\mathrm{C}_{15} \mathrm{H}_{24} \\
204.357 \\
\text { Sesquiterpene }\end{array}$ & & $\begin{array}{l}\text { PubChem CID } \\
12306054\end{array}$ & $\begin{array}{l}\text { Antimicrobial (54), Mutagenic and } \\
\text { Carcinogenic (55) }\end{array}$ \\
\hline $\begin{array}{l}\mathrm{Y} \text {-Cadinene } \\
\mathrm{C}_{15} \mathrm{H}_{24} \\
204.357 \\
\text { Sesquiterpene }\end{array}$ & & $\begin{array}{l}\text { PubChem CID } \\
92313\end{array}$ & Mutagenic and Carcinogenic (56) \\
\hline $\begin{array}{l}\text { Guaiol } \\
\mathrm{C}_{15} \mathrm{H}_{26} \mathrm{O} \\
222.372 \\
\text { Sesquiterpene alcohol }\end{array}$ & & $\begin{array}{l}\text { PubChem CID } \\
227829\end{array}$ & Antioxidant (25); Insecticidal (57) \\
\hline $\begin{array}{l}\alpha \text {-Cadinol } \\
\mathrm{C}_{15} \mathrm{H}_{26} \mathrm{O} \\
222.372 \\
\text { Sesquiterpene alcohol }\end{array}$ & & $\begin{array}{l}\text { PubChem CID } \\
519662\end{array}$ & Anti-mite activity (57) \\
\hline $\begin{array}{l}\text { Caryophyllene oxide } \\
\mathrm{C}_{15} \mathrm{H}_{24} \mathrm{O} \\
220.356 \\
\text { Sesquiterpene }\end{array}$ & & $\begin{array}{c}\text { PubChem CID } \\
1742210\end{array}$ & $\begin{array}{l}\text { Analgesic, Anti-inflammatory (58), } \\
\text { Antifungal (59), Anaesthetic (60) }\end{array}$ \\
\hline $\begin{array}{l}\text { Phytol } \\
\mathrm{C}_{20} \mathrm{H}_{40} \mathrm{O} \\
296.539 \mathrm{~g} / \mathrm{mol} \\
\text { Diterpene alcohol }\end{array}$ & & $\begin{array}{l}\text { PubChem CID } \\
296.539\end{array}$ & Antioxidant (25), Anticancerous (61) \\
\hline $\begin{array}{l}\text { Spathulenol } \\
\mathrm{C}_{15} \mathrm{H}_{24} \mathrm{O} \\
220.356 \mathrm{~g} / \mathrm{mol} \\
\text { Sesquiterpene alcohol }\end{array}$ & & $\begin{array}{l}\text { PubChem CID } \\
92231\end{array}$ & Antifungal (62) \\
\hline $\begin{array}{l}\text { Viridiflorol } \\
\mathrm{C}_{15} \mathrm{H}_{26} \mathrm{O} \\
222.372 \\
\text { Sesquiterpene alcohol }\end{array}$ & & $\begin{array}{l}\text { PubChem CID } \\
11996452\end{array}$ & $\begin{array}{l}\text { Anti-inflammatory, Antimycobacterial, } \\
\text { Antioxidant (63) }\end{array}$ \\
\hline
\end{tabular}


pneumonia, tuberculosis $(70)$, fever $(71,72)$, vomiting, food poisoning, stomach problems (17) and respiratory tract infections (68). Leaves are used to cure scabies and ringworms (73) and burning (74). Its leaves are also used as vegetable (75). A decoction of fresh leaves is given orally to cure dyspepsia (76). Bhattarai et al reported that the decoction of roots of Pogostemon plant along with the root of the plant of Ageratum conyzoides was used to cure typhoid by the local people of Nawalparasi district, Nepal (77). Fresh leaves of $P$. benghalensis are used in Southern Assam for the herbal preparation known as "Shuktani", which is used for the treatment of diarrhoea, dysentery, and indigestion, and also used by women for lactation and body strength after parturition (16). The young leaves are also used as a vegetable, and used to prepare pancake with powdered rice (78). The essential oil of $P$. benghalensis is used in the perfumery industry, and its dried leaves are used to scent cloth (79). Leaves and shoots of this plant are also used to extract natural colour and dyes (80), which are further used to decorate the wall of the houses (81). Various traditional uses of $P$. benghalensis are summarized in Table 2.

\section{Pharmacological activities}

Various pharmacological properties have been studied in plant $P$. benghalensis. Some of such activities like antibacterial, antiviral, antioxidant, antifungal, antiinflammatory of the plant are given in Table 3 and discussed below.

\section{Antibacterial activity}

Taylor et al reported that methanolic extracts of the aerial parts of $P$. benghalensis possessed antibacterial activity and inhibited the growth of bacteria Bacillus subtilis and Staphylococcus aureus at $2 \mathrm{~g} / \mathrm{mL}$ (11). Later on, Bhattarai et al reported that the methanolic extract of $P$. benghalensis from Nepal inhibited the growth of two gram-positive (Bacillus subtilis, Staphylococcus aureus) and two gram-negative bacteria (Escherichia coli, Pseudomonas aeruginosa), but was found inactive against bacteria Bacillus subtilis and Staphylococcus aureus (12). Thoppil et al studied the antibacterial activity of leaf essential oil of three species of genus Pogostemon (P. benghalensis, $P$. purpurascens, $P$. vestitus) against seven strains of bacteria. All three species of Pogostemon showed promising antibacterial activities against all the tested seven bacterial strains. However, the essential leaf oil of $P$. benghalensis was found to be the most effective in inhibiting bacterial growth. It inhibited the growth of Staphylococcus aureus with the highest inhibition zone $(39.33 \pm 1.53 \mathrm{~mm})$ as compared to the standard drug gentamycin sulphate with inhibition zone of diameter $35 \pm 1.0 \mathrm{~mm}$ (13). The methanolic extracts have been demonstrated to inhibit the growth of pathogenic bacteria, Bacillus subtilis and Salmonella typhi (66) thus, validating the traditional use of $P$. benghalensis as an antibacterial agent in the treatment of various ailments like typhoid, tuberculosis, dysentery, and wounds.

\section{Antiviral activity}

The traditional application of $P$. benghalensis for treatment of cold, cough, dysentery implies an antiviral activity of the plant. Taylor et al screened 21 species of medicinal plants including $P$. benghalensis for their antiviral activities against three mammalian viruses (Polio virus, Sindbis virus, Herpes simplex virus) and reported that methanolic extracts of the aerial parts of $P$. benghalensis had considerable antiviral activity. At $200 \mu \mathrm{g} / \mathrm{ml}$, it effectively inhibited the growth of Sindbis virus (14).

\section{Antifungal activity}

Traditionally, leaves of $P$. benghalensis have been used by local people of Panchthar district (Nepal) to cure scabies, ringworms, thus, implicating the antifungal property of the plant. Various extracts of $P$. benghalensis were reported to possess antifungal activity. The methanolic extracts of the aerial parts of this aromatic plant showed antifungal activity against Microsporum gypseum and Trichophyton mentagrophytes (11). Similarly, Thoppil et al (13) revealed the antifungal potential of crude essential oil of three species of genus Pogostemon including P. benghalensis against eight fungal strains, and reported that $P$. benghalensis inhibited the growth of Fusarium solani and Candida albicans with maximum inhibition zone of $32.33 \pm 2.08 \mathrm{~mm}$ and $32.33 \pm 2.52 \mathrm{~mm}$, respectively over the standard antibiotic nystatin (inhibition zone; $30.33 \pm 1.53$ ).

\section{Antioxidant activity}

In a study conducted by Singh et al, the antioxidant activity of crude essential oil of ten species of family Lamiaceae including $P$. benghalensis was evaluated through 1,1-diphenyl-2-picrylhydrazyl radical (DPPH) scavenging activity and total antioxidant activity (TAA). The essential oil of $P$. benghalensis exhibited DPPH scavenging activity and TAA with an EC50 (Halfmaximal Effective Concentration) value of 171.3 \pm 5.74 $\mu \mathrm{g} / \mathrm{mL}, 89.5 \pm 2.33 \mu \mathrm{g} / \mathrm{mL}$, respectively whereas, the EC50 value of standard butylated hydroxytoluene (BHT) for DPPH scavenging activity and standard ascorbic acid for TAA were 156.4 and $165.7 \mu \mathrm{g} / \mathrm{mL}$. The EC50 value of Pogostemon oil was nearly close to the standard value for DPPH scavenging activity, and the EC50 for TAA was lower than the standard value (10).

\section{Larvicidal activity}

Anjana and Thoppil evaluated the larvicidal potential of essential oil of four species of genus Pogostemon including $P$. benghalensis against the fourth instar larvae of Aedes albopictus Skuse. P. benghalensis essential oil showed 100\% larval mortality at 100 and $200 \mathrm{ppm}$ concentrations and the activity was attributed to sesquiterpene rich essential oil (9). Several reports have confirmed the larvicidal 
Table 2. Traditional uses of Pogostemon benghalensis

\begin{tabular}{|c|c|c|c|c|c|}
\hline Place & Local name & Part used & Administration & Traditional uses & References \\
\hline Uttra Pradesh, India & Maspindi & Leaves & Juice & It is applied on the cut and injuries to stop bleeding. & 82 \\
\hline Assam, India & Rujanto & Leaves & Leaf & As leafy vegetable to cure stomach problems & 83 \\
\hline Nawalparasi District, Central Nepal & Bhati & Whole plant & Decoction & To cure cold, cough and typhoid & 12 \\
\hline Udhampur district, Jammu and Kashmir, India & Kali suaali & Leaves & Decoction & To cure cold, cough and dyspepsia & 76 \\
\hline Kumaun, Uttrakhand, India & Pacholi & Leaves & - & Used to scent linen, shawls etc. & 79 \\
\hline Assam, India & Rujanto & Leaves & Paste & $\begin{array}{l}\text { To make Shuktani (ethno-medico recipe) along with other } 34 \\
\text { angiosperms. }\end{array}$ & 16 \\
\hline Panchthar district, Nepal & - & Leaves & & To cure scabies and ringworms & 73 \\
\hline Western Chitwan, Nepal & Rudhilo & Leaves and young shoot & Dye & Used for decoration of house wall & 81 \\
\hline Una, Himachal Pradesh, India & Kalibausti & Leaves & Chewing & as anti-diabetic remedy & 84 \\
\hline Ahmednagar (Western Ghat), Maharashtra, India & Phangala & Root & Juice and paste & Boiled root juice is given orally and paste is applied on snake bite site & 67 \\
\hline Chepang community, Chitwan District, Nepal & Rudilo & Leaves, root & - & To cure fever, malaria, pneumonia, tuberculosis & 70 \\
\hline Bhilla tribe, Maharshtra, India & Phangala & Leaves & Juice & $\begin{array}{l}\text { Leaf juice along with the dried gums of Sturculia urens fried in til oil, is } \\
\text { taken orally to cure piles. }\end{array}$ & 85 \\
\hline $\begin{array}{l}\text { Bagata tribe, Visakhapatnam district, Andhra } \\
\text { Pradesh, India }\end{array}$ & Gondri poolu & Leaves, roots & - & To cure fever, digestive disorders, & 72 \\
\hline Tehrathum district, Eastern Nepal & Rudilo & Roots, leaves & - & To cure haemorrhage & 69 \\
\hline Assam, India & Sukloti & Leaves & Juice & To stop bleeding & 86 \\
\hline Salem district, Tamil Nadu & Arissikaai & Fruits & - & Edible & 87 \\
\hline Chitwan, Nepal & Rudhilo & Leaves & - & To cure typhoid, sinusitis & 80 \\
\hline Nawarangpur district, Odisha, India & Gonda-dulia, Ishwarjata, Puka-sunga & Leaves & Paste & To cure spondylitis & 88 \\
\hline Maharashtra, India & - & Leaves & Fumigation & To repel insect & 89 \\
\hline Uttarakhand, India & Lojad & Leaves & Paste & To cure boils and blisters & 90 \\
\hline Rangamati District, Bangladesh & Lomboi Shak & Laeves & - & As leafy vegetable & 91 \\
\hline
\end{tabular}


Table 3. Pharmacological activity of Pogostemon benghalensis

\begin{tabular}{|c|c|c|c|c|c|}
\hline Activity & Plant part & Extract & Dose-range & Action & Sources \\
\hline Antioxidant & Leaves & EO & $50-400 \mu \mathrm{g} / \mathrm{mL}$ & Scavenging of free radicals & 10 \\
\hline \multirow{3}{*}{ Antibacterial } & Aerial part & ME & $2 \mathrm{~g}$ dried plant material $/ \mathrm{mL}$ & $\begin{array}{l}\text { Growth inhibition of Bacillus subtilis and } \\
\text { Staphylococcus aureus bacteria }\end{array}$ & 11 \\
\hline & Aerial part & ME & 1g dried plant material/mL & $\begin{array}{l}\text { Inhibited the growth of } E \text {. coli and Pseudomonas } \\
\text { aeruginosa }\end{array}$ & 12 \\
\hline & Leaf & EO & Dilution 1:0,1:1,1:2 in diethyl ether & Inhibited bacterial growth & 13 \\
\hline Antiviral & Aerial part & $\mathrm{ME}$ & $400 \mu \mathrm{g}$ crude plant extract $/ \mathrm{mL}$ & Inhibited growth of SINV & 14 \\
\hline \multirow{2}{*}{ Antifungal } & Aerial part & ME & $2 \mathrm{~g}$ dried plant material $/ \mathrm{mL}$ & Showed antifungal activity & 11 \\
\hline & Leaf & EO & Dilution 1:0,1:1,1:2 in diethyl ether & Showed antifungal activity against 8 strains of fungi & 13 \\
\hline Larvicidal & Leaf & EO & $5-200$ ppm & $\begin{array}{l}\text { Showed } 100 \% \text { larvicidal activity at conc. } 100 \text { and } \\
200 \text { ppm }\end{array}$ & 9 \\
\hline Anticancerous & Leaf & HEAE & $5-2000 \mathrm{mg} / \mathrm{kg}$ body weight & Showed anticancerous activity & 15 \\
\hline
\end{tabular}

Abbreviations: EO, essential oil; ME, methanolic extract; HEAE, Hydroethanolic and aqueous extract; SINV, Sindbis virus

activity of sesquiterpenes (92-94).

\section{Anticancerous activity}

Patel et al reported the anti-tumour activity of $P$. benghalensis and reported that MST (Median Survival Time) of tumor-bearing mice significantly increased when treated with HEEPB (hydroethanolic extracts), AEPB (aqueous extracts) and 5-FU (5-Fluorouracil) over tumor control. After one month, reported tumor volume was $\sim 1.90 \mathrm{ml} \sim 1.67$ and $1.62 \mathrm{ml}$ for the mice groups treated with $5-\mathrm{FU}(20 \mathrm{mg} / \mathrm{kg})$, HEEPB $(500 \mathrm{mg} / \mathrm{kg})$ and AEPB (500 mg/kg), respectively, over the tumor control mice with $\sim 3 \mathrm{ml}$ of tumor volume (15).

\section{Conclusions}

The present review congregated information about the botanical aspects, ethnobotanical uses and recent studies on phytochemistry, and biological activities of different extracts of $P$. benghalensis. Essential oil is highly rich in sesquiterpenes. Various studies have evaluated the anticancerous, antibacterial, antifungal, antiviral, antioxidant and larvicidal properties of the essential oil and different extracts of $P$. benghalensis. It has been found that essential oil and various extracts of $P$. benghalensis possess good pharmacological potential and have broad spectrum activities on various ailments as evident from the traditional knowledge and reported bioassays. Despite ample traditional uses of $P$. benghalensis, only limited in vivo model studies have been conducted to evaluate its pharmacological properties. Therefore, there is an utmost need for in vivo clinical trials to confirm these pharmacological activities. To further strengthen the pharmacological profile of $P$. benghalensis for drug development, more rigorous research should be conducted on the extraction, identification and the mode of action of the bioactive components at the molecular level. Further, more investigations are required to elucidate the correlation between traditional uses and its pharmacological activities.

\section{Acknowledgment}

Sangeeta Dahiya is thankful to University Grant Commission (UGC-BSR), New Delhi, for the financial assistant.

\section{Authors' contributions}

SD wrote the first draft of the paper. DRB and HPS did critical revision. All authors read and approved final version of the manuscript.

\section{Conflict of interest}

None to declare

\section{Ethical considerations}

Ethical issues have been observed by the authors.

\section{Funding/Support}

University Grant Commission (UGC-BSR), New Delhi supported the study.

\section{References}

1. Atanasov AG, Waltenberger B, Pferschy-Wenzig EM, Linder T, Wawrosch C, Uhrin P, et al. Discovery and resupply of pharmacologically active plant-derived natural products: a review. Biotechnol Adv. 2015;33(8):1582-614. doi: 10.1016/j.biotechadv.2015.08.001.

2. Mathew NS, Negi PS. Traditional uses, phytochemistry and pharmacology of wild banana (Musa acuminata Colla): a review. J Ethnopharmacol. 2017;196:124-40. doi: 10.1016/j. jep.2016.12.009.

3. Adhikari PP, Talukdar S, Borah A. Ethnomedicobotanical study of indigenous knowledge on medicinal plants used for the treatment of reproductive problems in Nalbari district, Assam, India. J Ethnopharmacol. 2018;210:386407. doi: 10.1016/j.jep.2017.07.024. 
4. Bakkali F, Averbeck S, Averbeck D, Idaomar M. Biological effects of essential oils--a review. Food Chem Toxicol. 2008;46(2):446-75. doi: 10.1016/j.fct.2007.09.106.

5. Dhakal D, Joshi S, Dhakal PD. Chemical composition of the essential oil of Pogostemon bengalensis (Burm.f.) Kuntze from Nepal. Nat Prod Commun. 2014;9:1-2.

6. Bhuiyan MNI, Varshney VK, Varshney SC, Tomar A, Akter F. Composition of essential oil of the leaf and inflorescence of Pogostemon benghalensis (Burm.f.) Kuntze. Int Res J Plant Sci. 2011;2(9):271-5.

7. Distribution of Pogostemon benghalensis in Bhutan. Available from: https://biodiversity.bt/observation/ show/54648?pos=\#. Accessed March 12, 2019.

8. Chanotiya CS, Yadav A, Singh AK, Mathela CS. Composition of the leaf and inflorescence essential oil of Pogostemon benghalensis (Burm.f.) from Kumaon. Nat Prod Commun. 2007;2(9):941-4.

9. Anjana S, Thoppil JE. Chemical composition of essential oils of Pogostemon spp. and their larvicidal activity against Aedes albopictus Skuse (Diptera: Culicidae). Int J Environ Biol. 2013;3(1):26-31.

10. Singh S, Batish DR, Kohli RK, Singh HP. An evaluation of the antioxidant properties of some oil yielding lamiaceous plants from Morni hills (Haryana, India). Int J Pharm Sci Res. 2015;6(3):1078-82. doi: 10.13040/ ijpsr.0975-8232.6(3).1078-82.

11. Taylor RS, Manandhar NP, Towers GH. Screening of selected medicinal plants of Nepal for antimicrobial activities. J Ethnopharmacol. 1995;46(3):153-9. doi: 10.1016/03788741(95)01242-6.

12. Bhattarai S, Chaudhary RP, Taylor RS, Ghimire SK. Biological activities of some Nepalese medicinal plants used in treating bacterial infections in human beings. Nepal J Sci Technol. 2009;10:83-90. doi: 10.3126/njst.v10i0.2830.

13. Thoppil JE, Tajo A, Minija J, Deena MJ, Sreeranjini K, Leeja L, et al. Antimicrobial activity of the essential oils of three species of Pogostemon. J Environ Biol. 2014;35(5):795-8.

14. Taylor RS, Manandhar NP, Hudson JB, Towers GH. Antiviral activities of Nepalese medicinal plants. J Ethnopharmacol. 1996;52(3):157-63. doi: 10.1016/0378-8741(96)01409-2.

15. Patel MS, Antala BV, Dowerah E, Senthilkumar R, Lahkar M. Antitumor activity of Pogostemon benghalensis Linn. on ehrlich ascites carcinoma tumor bearing mice. J Cancer Res Ther. 2014;10(4):1071-5. doi: 10.4103/0973-1482.138014.

16. Nath A, Maiti GG. Shuktani - a new ethno-medico recipe among the Sylheti Bengali Community of Barak valley, Southern Assam, India. Indian J Tradit Know. 2012;11(1):156-60.

17. Sen P, Dollo M, Choudhury MD, Choudhury D. Documentation of traditional herbal knowledge of Khamptis of Arunachal Pradesh. Indian J Tradit Know. 2008;7(3):438-42.

18. Pogostemon benghalensis (Burm.f.) Kuntze is an accepted name. Available from: http://www.theplantlist.org/tpl1.1/ record/kew-162090. Accessed March 1, 2019.

19. Pradeep DP, Murugan K. Scanning electron and light microscopic characters related with taxonomic treatment of the medicinal plant Pogostemon benghalensis (Burm.f.) Kuntze in comparison to patchouli (Lamiaceae). World J Pharm Pharm Sci. 2013;2:6336-51.

20. Anonymous. Pogostemon benghalensis. The Wealth of India - Raw Materials, Reprinted Series, Vol. VIII (Ph-Re). In:
Krishnamurthi A, ed. New Delhi: Council of Scientific and Industrial Research; 2003. p. 177-83.

21. Suhali K. Flora of Pakistan. Available from: http:// www.efloras.org/florataxon.aspx?flora_id=5\&taxon id $=230004828$. Accessed February 24, 2019.

22. Paulraj MG, Reegan AD, Ignacimuthu S. Toxicity of benzaldehyde and propionic acid against immature and adult stages of Aedes aegypti (Linn.) and Culex quinquefasciatus (Say) (Diptera: Culicidae). J Entomol. 2011;8(6):539-47. doi: 10.3923/je.2011.539.547.

23. Guimarães AG1, Quintans JS, Quintans LJ Jr. Monoterpenes with analgesic activity--a systematic review. Phytother Res. 2013;27(1):1-15. doi: 10.1002/ptr.4686.

24. Wang W, Li N, Luo M, Zu Y, Efferth T. Antibacterial activity and anticancer activity of Rosmarinus officinalis L. essential oil compared to that of its main components. Molecules. 2012;17(3):2704-13. doi: 10.3390/molecules17032704.

25. Ruberto G, Baratta MT. Antioxidant activity of selected essential oil components in two lipid model systems. Food Chem. 2000;69(2):167-74. doi: 10.1016/s03088146(99)00247-2.

26. Haselton AT, Acevedo A, Kuruvilla J, Werner E, Kiernan J, Dhar P. Repellency of alpha-pinene against the house fly, Musca domestica. Phytochemistry. 2015;117:469-75. doi: 10.1016/j.phytochem.2015.07.004.

27. Orhan I, Küpeli E, Aslan M, Kartal M, Yesilada E. Bioassayguided evaluation of anti-inflammatory and antinociceptive activities of pistachio, Pistacia vera L. J Ethnopharmacol. 2006;105(1-2):235-40. doi: 10.1016/j.jep.2005.10.023.

28. Bourgou S, Pichette A, Marzouk B, Legault J. Bioactivities of black cumin essential oil and its main terpenes from Tunisia. S Afr J Bot. 2010;76(2):210-6. doi: 10.1016/j. sajb.2009.10.009.

29. Santana MF, Quintans-Júnior LJ, Cavalcanti SC, Oliveira MG, Guimarães AG, Cunha ES, et al. p-Cymene reduces orofacial nociceptive response in mice. Rev Bras Farmacogn. 2011;21(6):1138-43. doi: 10.1590/s0102$695 \times 2011005000156$.

30. Adekunle OK, Acharya R, Singh B. Toxicity of pure compounds isolated from Tagetes minuta oil to Meloidogyne incognita. Australas Plant Dis Notes. 2007;2(1):101-4. doi: 10.1071/DN07042.

31. Kordali S, Usanmaz A, Bayrak N, Çakır A. Fumigation of volatile monoterpenes and aromatic compounds against adults of Sitophilus granarius (L.) (Coleoptera: Curculionidae). Rec Nat Prod. 2017;11(4):362-73.

32. Gu Y, Ting Z, Qiu X, Zhang X, Gan X, Fang Y, et al. Linalool preferentially induces robust apoptosis of a variety of leukemia cells via upregulating p53 and cyclin-dependent kinase inhibitors. Toxicology. 2010;268(1-2):19-24. doi: 10.1016/j.tox.2009.11.013.

33. Peana AT, D’Aquila PS, Panin F, Serra G, Pippia P, Moretti MD. Anti-inflammatory activity of linalool and linalyl acetate constituents of essential oils. Phytomedicine. 2002;9(8):721-6. doi: 10.1078/094471102321621322.

34. Badawy ME, El-Arami SA, Abdelgaleil SA. Acaricidal and quantitative structure activity relationship of monoterpenes against the two-spotted spider mite, Tetranychus urticae. Exp Appl Acarol. 2010;52(3):261-74. doi: 10.1007/s10493010-9363-y.

35. Taheri Mirghaed A, Ghelichpour M, Hoseini SM. Myrcene and linalool as new anesthetic and sedative agents in 
common carp, Cyprinus carpio - Comparison with eugenol. Aquaculture. 2016;464:165-70. doi: 10.1016/j. aquaculture.2016.06.028.

36. Barocelli E, Calcina F, Chiavarini M, Impicciatore M, Bruni $\mathrm{R}$, Bianchi A, et al. Antinociceptive and gastroprotective effects of inhaled and orally administered Lavandula hybrida Reverchon "Grosso" essential oil. Life Sci. 2004;76(2):213-23. doi: 10.1016/j.lfs.2004.08.008.

37. Slamenová D, Horváthová E, Wsólová L, Sramková M, Navarová J. Investigation of anti-oxidative, cytotoxic, DNAdamaging and DNA-protective effects of plant volatiles eugenol and borneol in human-derived HepG2, Caco-2 and VH10 cell lines. Mutat Res. 2009;677(1-2):46-52. doi: 10.1016/j.mrgentox.2009.05.016.

38. Su J, Lai H, Chen J, Li L, Wong YS, Chen T, et al. Natural borneol, a monoterpenoid compound, potentiates selenocystine-induced apoptosis in human hepatocellular carcinoma cells by enhancement of cellular uptake and activation of ROS-mediated DNA damage. PLoS One. 2013;8(5):e63502. doi: 10.1371/journal.pone.0063502.

39. Wang S, Zhang D, Hu J, Jia Q, Xu W, Su D, et al. A clinical and mechanistic study of topical borneol-induced analgesia. EMBO Mol Med. 2017;9(6):802-15. doi: 10.15252/ emmm.201607300.

40. Choi WS, Park BS, Lee YH, Jang DY, Yoon HY, Lee SE. Fumigant toxicities of essential oils and monoterpenes against Lycoriella mali adults. Crop Prot. 2006;25(4):398401. doi: 10.1016/j.cropro.2005.05.009.

41. Mulyaningsih S, Youns M, El-Readi MZ, Ashour ML, Nibret E, Sporer F, et al. Biological activity of the essential oil of Kadsura longipedunculata (Schisandraceae) and its major components. J Pharm Pharmacol. 2010;62(8):103744. doi: 10.1111/j.2042-7158.2010.01119.x.

42. Fang Y, Kang Y, Zou H, Cheng X, Xie T, Shi L, et al. beta-elemene attenuates macrophage activation and proinflammatory factor production via crosstalk with Wnt/ beta-catenin signaling pathway. Fitoterapia. 2018;124:92102. doi: 10.1016/j.fitote.2017.10.015.

43. Yao CC, Tu YR, Jiang J, Ye SF, Du HX, Zhang Y. betaelemene reverses the drug resistance of lung cancer A549/ DDP cells via the mitochondrial apoptosis pathway. Oncol Rep. 2014;31(5):2131-8. doi: 10.3892/or.2014.3083.

44. Turkez H, Togar B, Di Stefano A, Taspinar N, Sozio P. Protective effects of cyclosativene on $\mathrm{H} 2 \mathrm{O} 2$-induced injury in cultured rat primary cerebral cortex cells. Cytotechnology. 2015;67(2):299-309. doi: 10.1007/s10616013-9685-9.

45. Chavan MJ, Wakte PS, Shinde DB. Analgesic and antiinflammatory activities of the sesquiterpene fraction from Annona reticulata L. bark. Nat Prod Res. 2012;26(16):15158. doi: 10.1080/14786419.2011.564583.

46. Turkez H, Togar B, Tatar A, Geyıkoglu F, Hacımuftuoglu A. Cytotoxic and cytogenetic effects of a-copaene on rat neuron and N2a neuroblastoma cell lines. Biologia. 2014;69(7):936-42. doi: 10.2478/s11756-014-0393-5.

47. Soares DC, Portella NA, Ramos MF, Siani AC, Saraiva EM. Trans-beta-caryophyllene: an effective antileishmanial compound found in commercial copaiba oil (Copaifera spp.). Evid Based Complement Alternat Med. 2013;2013:761323. doi: 10.1155/2013/761323.

48. Dahham SS, Tabana YM, Iqbal MA, Ahamed MB, Ezzat MO, Majid AS, et al. The anticancer, antioxidant and antimicrobial properties of the sesquiterpene beta-caryophyllene from the essential oil of Aquilaria crassna. Molecules. 2015;20(7):11808-29. doi: 10.3390/ molecules200711808.

49. Fernandes ES, Passos GF, Medeiros R, da Cunha FM, Ferreira J, Campos MM, et al. Anti-inflammatory effects of compounds alpha-humulene and (-)-trans-caryophyllene isolated from the essential oil of Cordia verbenacea. Eur J Pharmacol. 2007;569(3):228-36. doi: 10.1016/j. ejphar.2007.04.059.

50. Sawant SS, Youssef DT, Sylvester PW, Wali V, El Sayed KA. Antiproliferative sesquiterpenes from the Red Sea soft coral Sarcophyton glaucum. Nat Prod Commun. 2007;2(2):1-3. doi: 10.1177/1934578x0700200201.

51. Bruce TJ, Birkett MA, Blande J, Hooper AM, Martin JL, Khambay B, et al. Response of economically important aphids to components of Hemizygia petiolata essential oil. Pest Manag Sci. 2005;61(11):1115-21. doi: 10.1002/ps.1102.

52. Kiran SR, Devi PS. Evaluation of mosquitocidal activity of essential oil and sesquiterpenes from leaves of Chloroxylon swietenia DC. Parasitol Res. 2007;101(2):413-8. doi: 10.1007/s00436-007-0485-z.

53. Hsu HC, Yang WC, Tsai WJ, Chen CC, Huang HY, Tsai YC. Alpha-bulnesene, a novel PAF receptor antagonist isolated from Pogostemon cablin. Biochem Biophys Res Commun. 2006;345(3):1033-8. doi: 10.1016/j.bbrc.2006.05.006.

54. Pérez-López A, Cirio AT, Rivas-Galindo VM, Aranda RS, de Torres NW. Activity against Streptococcus pneumoniae of the essential oil and $\delta$-cadinene isolated from Schinus molle fruit. J Essent Oil Res. 2011;23(5):25-8. doi: 10.1080/10412905.2011.9700477.

55. Balaji S, Chempakam B. Mutagenicity and carcinogenicity prediction of compounds from cardamom (Elettaria cardamom Maton). Ethnobot Leaflets. 2008;12:682-9.

56. Liu T, Wang CJ, Xie HQ, Mu Q. Guaiol--a naturally occurring insecticidal sesquiterpene. Nat Prod Commun. 2013;8(10):1353-4.

57. Chang ST, Chen PF, Wang SY, Wu HH. Antimite activity of essential oils and their constituents from Taiwania cryptomerioides. J Med Entomol. 2001;38(3):455-7. doi: 10.1603/0022-2585-38.3.455.

58. Chavan MJ, Wakte PS, Shinde DB. Analgesic and antiinflammatory activity of caryophyllene oxide from Annona squamosa L. bark. Phytomedicine. 2010;17(2):149-51. doi: 10.1016/j.phymed.2009.05.016.

59. Yang D, Michel L, Chaumont JP, Millet-Clerc J. Use of caryophyllene oxide as an antifungal agent in an in vitro experimental model of onychomycosis. Mycopathologia. 1999;148(2):79-82. doi: 10.1023/a:1007178924408.

60. Ghelardini C, Galeotti N, Di Cesare Mannelli L, Mazzanti G, Bartolini A. Local anaesthetic activity of betacaryophyllene. Farmaco. 2001;56(5-7):387-9. doi: 10.1016/ s0014-827x(01)01092-8.

61. Sheeja L, Lakshmi D, Bharadwaj S, Parveen KS. Anticancer activity of phytol purified from Gracilaria edulis against human breast cancer cell line (MCF-7). Int J Curr Sci. 2016;19(4):36-46.

62. Hubert TD, Wiemer DF. Ant-repellent terpenoids from Melampodium divaricatum. Phytochemistry. 1985;24(6):1197-8. doi: 10.1016/S0031-9422(00)81099-7.

63. Trevizan LNF, Nascimento KFD, Santos JA, Kassuya CAL, Cardoso CAL, Vieira MDC, et al. Anti-inflammatory, 
antioxidant and anti-Mycobacterium tuberculosis activity of viridiflorol: The major constituent of Allophylus edulis (A. St.-Hil., A. Juss. \& Cambess.) Radlk. J Ethnopharmacol. 2016;192:510-5. doi: 10.1016/j.jep.2016.08.053.

64. Unni BG, Borah A, Wann SB, Singh HR, Devi B, Bhattacharjee M. Phytochemical and antibacterial study of traditional medicinal plants of north east India on Escherichia coli. Asian J Exp Sci. 2009;23(1):103-8.

65. Muthuraj K, Shalimol A, Sivapriya KT, Nagarajan N. Screening of active phytocompounds by GC-MS analysis and in vitro antibacterial activity of endemic plant Pogostemon mollis benth. International Journal of Recent Advances in Multidisciplinary Research. 2015;2(7):534-9.

66. Naise MG, Bhadaange DG. In-vitro antibacterial activity of Pogostemon benghalensis (N. Burman) Kuntz. Lamiaceae plant from Melghat (M.S.) India. Int J Appl Res. 2017;x:2289.

67. Khyade MS, Takate YA, Divekar MV. Plants used as an antidote against snakebite in Akole Taluka of Ahmednagar district (MS), India. J Nat Rem. 2011;11(2):182-92. doi: $10.18311 /$ jnr/2011/443.

68. Saikia P, Khan ML. Diversity of medicinal plants and their uses in homegardens of upper Assam, Northeast India. Asian J Pharm Biol Res. 2011;1:296-309.

69. Rai MB. Medicinal plants of Tehrathum district, Eastern Nepal. Our Nature. 2003;1(1):42-8.

70. Magar DT, Regmi PP, Dutta JP, Pandit BH, Paudel IH, Subedi MS. Natural resources utilization: a case of nontimber forest products in Chepang community of Chitwan district, Nepal. Agric Dev. 2011;8:97-108.

71. Dangol DR. Traditional uses of plants of Commonl and habitats in Western Chitwan, Nepal. J Inst Agric Anim Sci. 2008;29:71-8.

72. Padal SB, Ramakrishna H, Devender R. Ethnomedicinal studies for endemic diseases by the tribes of Munchingiputtu Mandal, Visakhapatnam district, Andhra Pradesh, India. Int J Med Arom Plants. 2012;2(3):453-9.

73. Gautam TP. Indigenous uses of some medicinal plants in Panchthar district, Nepal. Nepalese J Biosci. 2011;1:125-30. doi: $10.3126 /$ njbs.v1i0.7479.

74. Dutt B. Ethnobiology in Human Welfare. In: SK Jain, ed. New Delhi: Deep Publications; 1996. p. 400-2.

75. Lokho K, Narasimhan D. Ethnobotany of Mao-Naga Tribe of Manipur, India. Pleione. 2013;7(2):314-24.

76. Bhatia H, Sharma YP, Manhas RK, Kumar K. Ethnomedicinal plants used by the villagers of district Udhampur, J\&K, India. J Ethnopharmacol. 2014;151(2):1005-18. doi: 10.1016/j.jep.2013.12.017

77. Bhattarai S, Chaudhary RP, Taylor RS. Ethno-medicinal plants used by the people of Nawalparasi District, Central Nepal. Our Nature. 2009;7(1):82-99.

78. Patiri B, Borah A. Wild Edible Plants of Assam. Guwahati: Geetakhi Printers and Publishers; 2007. p. 105.
79. Mathur A, Joshi H. Ethnobotanical studies of the Tarai region of Kumaun, Uttarakhand, India. Ethnobot Res Appl. 2013;11:174-203.

80. Poudel M, Singh NB. Medical ethnobiology and indigenous knowledge system found in Darai ethnic group of Chitwan, Nepal. J Inst Sci Technol. 2016;21(1):103-11.

81. Dangol DR. Economic uses of forest plant resources in western Chitwan, Nepal. Banko Janakari. 2002;12(2):56-64.

82. Ali ZA, Ahmad S, Khan LA. Ethnopharmacological survey of Rampur district forests in Rohilkhand region of Uttar Pradesh. Hippo J Unani Med. 2012;7:93-100.

83. Nath A, Maiti GG. An ethnobotanical report on less-known leafy vegetables consumed by different communities of Barak valley, Assam, India. Ecobios. 2011;4:45-55.

84. Gupta S, Sidhu MC, Ahluwalia AS. Plant-based remedies for the management of diabetes. Curr Bot. 2017;8:34-40. doi: 10.19071/cb.2017.v8.3169.

85. Kamble SY, Patil SR, Sawant PS, Sawant S, Pawar SG, Singh EA. Studies on plants in traditional medicine by Bhilla tribe of Maharashtra. Indian J Tradit Know. 2010;9(3):591-8.

86. Purkayastha J, Dutta M, Nath S C. Ethnomedicinal plants from Dibru-Saikhowa biosphere reserve, Assam. Indian J Tradit Know. 2007;6(3):477-80.

87. Ranjithakani P, Geetha S, Lakshmi G, Murugan S. Preliminary survey of wild edibles of kolli hills of salem. Anc Sci Life. 1992;11(3-4):133-6.

88. Dhal NK, Panda SS, Muduli SD. Traditional uses of medicinal plants by native people in Nawarangpur district, Odisha, India. Asian J Plant Sci Res. 2015;5(2):27-33.

89. Kulkarni S, Kulkarni DK, Deo AD, Pande AB, Bhagat RL. Use of ethno-veterinary medicines (EVM) from Vidarbha region (MS) India. Biosci Discov. 2014;5(2):180-6.

90. Sharma J, Gaur RD, Gairola S, Painuli RM, Siddiqi TO. Traditional herbal medicines used for the treatment of skin disorders by the Gujjar tribe of Sub-Himalayan tract, Uttarakhand. Indian J Tradit Know. 2013;12(4):736-46.

91. Khatun M, Hassan MA, Islam SN, Rahman MO. Taxonomy of the leafy vegetables in Bangladesh. Bangladesh J Plant Taxon. 2013;20(1):95-123.

92. Arriaga AMC, Malcher GT, Lima JQ, Magalhães FEA, Gomes TMBM, Da Conceição $\mathrm{M}$, et al. Composition and larvicidal activity of the essential oil from Tephrosia cinerea Pers. J Essent Oil Res. 2008;20(5):450-1. doi: 10.1080/10412905.2008.9700056.

93. Lima MA, de Oliveira FFM, Gomes GA, Lavor PL, Santiago GM, Nagao-Dias AT, et al. Evaluation of larvicidal activity of the essential oils of plants species from Brazil against Aedes aegypti (Diptera: Culicidae). Afr J Biotechnol. 2011;10(55):11716-20. doi: 10.5897/ajb11.1102.

94. Pavela R. Essential oils for the development of eco-friendly mosquito larvicides: a review. Ind Crops Prod. 2015;76:17487. doi: 10.1016/j.indcrop.2015.06.050. 